\title{
Resilience of Alternative Stable States during the Recovery of Shallow Lakes from Eutrophication: Lake Veluwe as a Case Study
}

\author{
Bas W. Ibelings, ${ }^{1,2, *}$ Rob Portielje, ${ }^{2}$ Eddy H. R. R. Lammens, ${ }^{2}$ \\ Ruurd Noordhuis, ${ }^{2}$ Marcel S. van den Berg, ${ }^{2}$ Willemien Joosse, ${ }^{4}$ and \\ Marie Louise Meijer ${ }^{2,5}$
}

\begin{abstract}
${ }^{1}$ Eawag, Seestrasse 79, 6047 Kastanienbaum, Switzerland; ${ }^{2}$ Institute for Inland Water Management and Waste Water Treatment, RIZA, P.O. Box 178200 AA, Lelystad, The Netherlands; ${ }^{3}$ Department of Foodweb Studies, Netherlands Institute of Ecology (NIOO KNAW), Centre for Limnology, Rijksstraatweg 6, 3631 AC, Nieuwersluis, The Netherlands; ${ }^{4}$ IDsW, P.O. Box 178200 AA, Lelystad, The Netherlands; ${ }^{5}$ Waterschap Hunze en Aa's, P.O. Box 1959640 AD, Veendam, The Netherlands
\end{abstract}

\begin{abstract}
In this paper we analyze a long-term dataset on the recovery from eutrophication of Lake Veluwe (The Netherlands). Clear hysteresis was observed in a number of ecosystem variables: the route to recovery differed significantly from the route that led to loss of clear water. The macrophyte dominated state disappeared in the late 1960s at TP above $0.20 \mathrm{mg} \mathrm{l}^{1}$, whereas its return occurred at less than $0.10 \mathrm{mg}$ TP ${ }^{1}{ }^{1}$. Several regime shifts resulting in the occurrence of three alternative stable states were observed over a period of 30 years. The turbid state showed resistance to change, despite a strong and prompt reduction in Chl-a following reduction of external P-loading. The most important component that determined hysteresis in the return to clear water was not internal P-loading, but a high level of nonalgal light attenuation (through sediment resuspension) maintained by the interaction between wind and benthivorous fish. Although Chara was able to re-colonize the most shallow parts of the lake, recovery stalled and for a number of years clear (above charophyte beds) and turbid (deeper parts of the lake) water co-existed, as a separate alternative
\end{abstract}

Received 8 November 2005; accepted 14 July 2006; published online 3 April 2007.

*Corresponding author; e-mail: bas.ibelings@eawag.ch state on route to full recovery. Lake-wide clear water was re-established after bream density had been reduced substantially. This allowed a return of zebra mussels to the lake, whose high filtration capacity helped in maintaining clear water. In this study, we were able to identify the main drivers of hysteresis and regime shifts, although formal demonstration of cause and effect was not possible on the basis of field data alone. We argue that resilience of the present clear water state of Lake Veluwe very much depends on sizable populations of a few keystone species, especially Chara (stoneworts) and Dreissena (zebra mussels), and that careful management of these species is equally important as control of nutrients. Lake management should strive to maintain and strengthen resilience of the ecosystem, and this should offer protection against a renewed collapse of the clear state.

Key words: alternative stable states; cyanobacteria; Chara; Dreissena; eutrophication; hysteresis; lake ecosystems; regime shift; resilience..

\section{INTRODUCTION}

Most of the shallow lakes in the Netherlands have shifted from clear water with abundant growth of 
macrophytes to turbid water characterized by blooms of cyanobacteria. Since 1980 a nationwide policy on reducing nutrient loads to surface waters has been implemented in the Netherlands. Additional restoration measures like biomanipulation or flushing have been applied to many lakes. As a consequence phosphorus concentrations and phytoplankton biomass have been reduced substantially in a majority of Dutch lakes, but transparency in many cases has not increased (Van Der Molen and Portielje 1999). The turbid state of these lakes thus appeared to be very stable and resistant to change.

Many observations have supported the existence of alternative stable states or equilibria in shallow lakes (Moss and others 1996; Korner 2001; Dent and others 2002; Bayley and Prather 2003; Dokulil and Teubner 2003; Jackson 2003). But although the occurrence of alternative states is easily observed, our understanding of these shifts is incomplete and requires the ongoing analysis of well documented cases. At low nutrient levels only the macrophyte dominated equilibrium exists in shallow lakes, whereas at high nutrient levels, only the turbid equilibrium dominated by phytoplankton is found. At intermediate nutrient levels, both stable states may occur. Transitions from one state to the other are sometimes referred to as regime shifts and they are often induced by an interaction between internal ecosystem processes and external fluctuations (Scheffer and others 2001; Scheffer and Carpenter 2003).

The clear water state is stabilized by a number of ecological feed-back mechanisms in which macrophytes often play a central role. Different mechanisms explain the stabilization of transparency by macrophytes. Macrophytes reduce sediment resuspension, increase sedimentation, compete for nutrients with algae and provide a refuge for zooplankton against predation by fish (Schriver and others 1995; Scheffer and others 1997; Van Den Berg and others 1998; Blindow and others 2002). Feed-back mechanisms between cyanobacteria and turbidity stabilize the turbid state. Dense blooms of filamentous cyanobacteria like Planktothrix agardhii promote the shady conditions on which they depend to out-compete other phytoplankton (Scheffer and others 1997). Another factor that stabilizes the turbid state is the build up of a pool of easily resuspendable matter during years of eutrophication. The absence of plants and the feeding behavior of benthivorous fish facilitate wind driven resuspension of the sediment and maintain the water in a turbid state (Scheffer and others 2003). These stabilizing factors cause a tendency of sys- tems to remain in the same state despite changes in external conditions, a process called hysteresis. Hysteresis refers to the phenomenon by which changes in states follow different pathways in forward and reverse direction, and is expected to occur in the restoration of shallow lakes from eutrophication (Scheffer 1998). The degree to which hysteresis occurs is dependent on system resilience.

The concept of resilience in ecology was introduced by Holling (1973) but multiple meanings of the concept have been published (discussion in Gunderson 2000). We refer to resilience as the magnitude of disturbance a system can absorb without shifting to an alternative stable state. Gradual changes like eutrophication or climate change initially may have little effect on the state of the system but they reduce resilience and make the system vulnerable to a regime shift (Lowe and others 2001). Although multiple stable states, hysteresis and resilience are theoretically well understood, and relevant for eutrophication management, field data that provide more than 'anecdotal' support and that offer an improved understanding of the underlying mechanisms are not easily obtained. One problem is that appropriately long-term data sets are scarce. In this paper we search for support for the occurrence of these phenomena during the recovery from eutrophication of one well-studied lake: Lake Veluwe in the Netherlands.

\section{Eutrophication Management of Lake Veluwe}

Lake Veluwe (Figure 1) forms part of a chain of large shallow lakes in the central part of the Netherlands. The lake was created in 1957 as a result of land reclamation in Lake IJsselmeer. The surface area of Lake Veluwe is 3,050 ha. It has a mean depth of $1.5 \mathrm{~m}$ and a maximum depth of about $5 \mathrm{~m}$ in a central navigation channel. A considerable area of the lake has a depth of less than $1 \mathrm{~m}$. The sediment in the shallow areas of the lake is sandy, whereas in the deeper parts silt has accumulated (Van Der Molen and others 1998). In Lake Veluwe, increased nutrient loading mainly from waste-water treatment plants and many small streams that have their catchments in agricultural areas caused a switch from the original clear water state to the turbid state. This switch was completed in the early 1970s when the last charophytes had disappeared and blooms of Planktothrix became established (Berger 1975, 1987; Hosper 1997). In 1979 the phosphorus loading to the lake was strongly reduced from more than 3 to about 


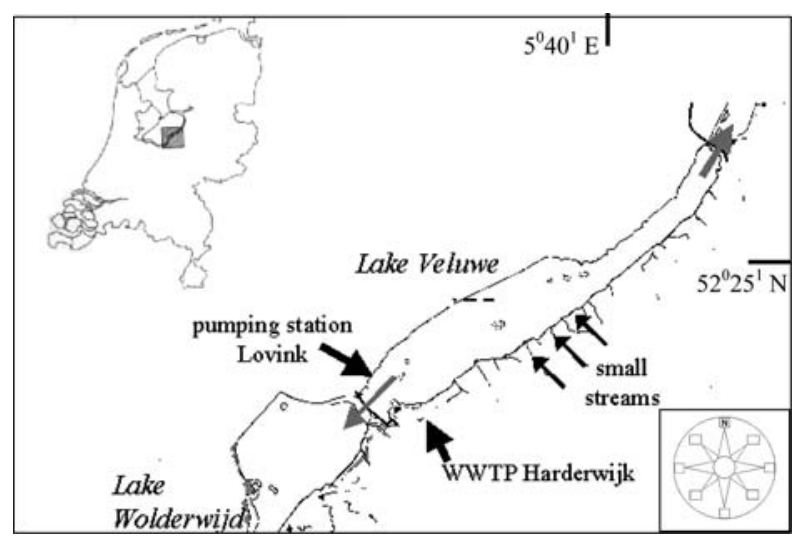

Figure 1. Map of Lake Veluwe and its neighboring lakes (adapted from Portielje and Rijsdijk 2003). Black arrows indicate inflow of nutrients; gray arrows the outflow from the lake to adjacent lakes.

$1 \mathrm{~g} \mathrm{~m}^{2} \mathrm{y}^{1}$. In that same year, flushing of the lake was begun. During the winter periods, water from the adjacent polder with low phosphorus and high calcium concentrations was pumped into the lake. In addition, measures were taken in the catchment's area of the small streams to further reduce nutrient loading of Lake Veluwe. Commercial fishery reduced the bream stock in Lake Veluwe by approximately $30 \mathrm{~kg} \mathrm{ha}^{1} \mathrm{y}^{1}$ between 1993 and 1998 (Lammens and others 2002).

\section{Methods Used in the Monitoring of Lake Veluwe}

Monitoring of water quality and biological communities in Lake Veluwe was carried out at monthly intervals (unless indicated otherwise) using the methods described below. More detailed descriptions have been presented elsewhere (Reeders and others 1998; Van Der Molen and others 1998; Portielje and Van Der Molen 1999; Van Den Berg and others 1999; Van Den Berg and others 2001; Lammens and others 2002; Noordhuis and others 2002; Portielje and Rijsdijk 2003). The following parameters were measured as follows:

- Transparency was recorded using a Secchi-disk and routinely measured in the deepest part of the lake, the shipping channel. Non-algal light attenuation was calculated from the inverse Secchi depth $1 / \mathrm{SD}\left(\mathrm{m}^{1}\right)$, which is the sum of the contributions of chlorophyll- $a(1 / \mathrm{SD})_{\mathrm{Chl}-a}$, light attenuation by water $(1 / \mathrm{SD})_{\mathrm{bck}}$, and a residual term $(1 / \mathrm{SD})_{\mathrm{res}}: \quad 1 / \mathrm{SD}=(1 / \mathrm{SD}) \mathrm{Chl}-a+(1 / \mathrm{SD}) \mathrm{res}+$ (1/SD)bck

- The term $(1 / S D)_{\text {res }}$ represents light attenuation by non-algal components such as suspended solids. From a multi-lake study on more than 200 shallow Dutch lakes, Portielje and Van der Molen (1999) estimated the contribution of (1/ $\mathrm{SD})_{\text {bck }}$ at $0.16 \mathrm{~m}^{1}$ and that of $(1 / \mathrm{SD})_{\mathrm{Chl}-a}$ at $0.011 \mathrm{~m}^{1}$.

- Non-algal light attenuation is therefore calculated as: $(1 / \mathrm{SD}) \mathrm{res}=(1 / \mathrm{SD})-0.16-0.011 \mathrm{Chl}-a$

- Total phosphorus (TP) Samples for nutrients, as well as for Chl- $a$ and plankton analysis, were collected using a $1.5 \mathrm{~m}$ long Perspex tube; samples from 5 to 6 locations were pooled to reach a final volume of $5 \mathrm{l}$, from which subsamples were taken for analysis. TP was measured according to Murphy and Riley (1962) after digestion with sulphuric acid/persulphate. Samples were analyzed starting in 1969. A value of $0.17 \mathrm{mg} \mathrm{P} \mathrm{l}^{1}$ was estimated for 1967 on the basis of the value for chemical oxygen demand (COD) in that year. From 1970-1977 the ratio of COD : TP averaged 19: 1 (Verdugt 1981), and this was used to calculate TP on the basis of a known value of COD in 1967.

- Chlorophyll-a (Chl-a) was measured spectrophotometrically at $625 \mathrm{~nm}$ after ethanol extraction; from 1971 onwards. Summer averages were obtained by averaging daily values for 1 April30 September, by linear interpolations between individual measurements.

- Phytoplankton were counted microscopically using the Uthermohl technique. Cell numbers were converted to biovolume using standard geometric conversion factors for the different species.

- Zooplankton were collected by filtering $25 \mathrm{l}$ of lake water over a net of $55 \mu \mathrm{m}$ mesh size, and counted using a dissection microscope.

- Chara coverage Between 1969 and 1987, data were collected by visually mapping the outlines of Chara spp. From 1987 onwards, the abundance of aquatic macrophytes in $100 \times 100 \mathrm{~m}$ grid cells was estimated yearly by sampling the submerged vegetation with a double headed reek (see Van den Berg and others 1999).

- Zebra mussels Density of mussels was estimated in 1974, 1987, 1991, 1992, 1993, 1996, 1998 and 2000. Samples were collected using a box-corer.

- Fish were sampled yearly from 1970 onwards using beam trawls. Biomass of benthic fish (mainly bream) was calculated per ha by dividing the total catch by the lake area covered and correcting for size-dependent catch deficiency (see Lammens and others 2004 for a detailed description).

- Waterfowl have been counted each month since 1957 (see Noordhuis and others 2002). Changes 
Table 1. Equations for the Relationships between the Abundance of Bird Populations and the Abundance of their Food (Chara spp for Herbivorous Birds and Dreissena polymorpha for Benthivorous Birds) in Lake Veluwe

\begin{tabular}{llll}
\hline Bird feeding guild & Equation & $R^{2}$ & $P$-value \\
\hline Herbivores (feeding on Chara) & $y=9.42 \times-0.32$ & 0.98 & $2.1 \times 10^{-22}$ \\
Benthivores (feeding on Dreissena) & $y=122.4 \times-16.4$ & 0.90 & $3.2 \times 10^{-4}$
\end{tabular}

$Y$ groups of birds in $\mathrm{kg}$ live weight; $X$ consumer abundance in $\mathrm{kg}$ live weight. Herbivores included mute swan, Bewick's swan, pintail, red-crested pochard, and coot. Benthivores included pochard, tufted-ducks and golden-eye.

in the level of eutrophication of lakes are often closely linked to changed use of the lake by water birds (Noordhuis and others 2002 and references therein). The close relationship between bird numbers and availability of their food was used to estimate Chara coverage and zebra mussel density in the 1960s, during the initial clear water state. These data are important in assessing the full extent of hysteresis. Although true measurements of Chara and mussels would have been preferable, the relationships used are sufficiently robust to warrant this approach. Methods and results are described by Noordhuis and others (2002). Equations used in the present study were developed on the basis of monitoring data from Lake Veluwe by Noordhuis (unpublished results) (see Table 1 for equations). The relationship between bird numbers and food availability and the independence of explanatory variables were examined using a Pearson product-moment correlation test. Using the regressions, Chara coverage and mussel densities during the 1960s were estimated. Model outcomes were successfully validated using data from lakes adjacent to Lake Veluwe (lakes Drontermeer and Wolderwijd) by comparing estimated values to actual counts in those two lakes. Model equations were evaluated by calculating $R^{2}$ and model efficiency (actual model fit).

In this paper, several statistical tests are used: the Pearson product-moment correlation test, the sign test and the Wilcoxon ranking test. The Pearson product moment correlation was used to relate bird numbers to their food (macrophytes and mussels); the coefficient is a measure of how well a linear equation describes the relation between two variables, $\mathrm{X}$ and $\mathrm{Y}$ measured on the same object. It is defined as the sum of products of the standard scores of the two measures, divided by the degrees of freedom. In the sign test, the hypothesis is tested that the $n$ plus and minus signs are sampled from a population in which two kinds of signs are present in equal proportions. It was used to test whether a relation between tur- bidity and TP in the period of increasing eutrophication (pre 1979) differed from an average relationship over the whole documented period. In the non-parametric Wilcoxon ranking test, two populations are combined and sorted in increasing order and subsequently numbered $(1 \ldots n)$. From the sum of the ranking order numbers of the member population, it can be calculated whether the distribution functions of the populations are significantly different. The test was used to test for significant differences in cumulative frequency distributions in Chl:TP and the nonalgal component of light attenuation during different stages of lake recovery (see Sokal and Rohlf 1995 for further explanations of the tests).

\section{Alternative States During Restoration}

Figure 2 shows data obtained from monitoring of Lake Veluwe: (a) TP; (b) Chl-a; (c) transparency; (d) vertical light attenuation coefficient not related to phytoplankton (in some literature referred to as background turbidity); (e) percentage of the phytoplankton and biovolume of Planktothrix agardhii; (f) total charophyte coverage; (g) numbers of Daphnia spp.; (h) density of zebra mussels (Dreissena polymorpha); (i) biomass of benthivorous fish, mainly bream (Abramis brama). In the history of Lake Veluwe, three alternative stable states can be distinguished, as theoretically predicted in Scheffer (1998): (1) a lake wide turbid state in which transparency was low throughout the lake, (2) an intermediate state in which clear and turbid water co-occurred, and (3) a lake wide clear water state. Criteria that distinguish between these states are given in Table 2. Ecosystem characteristics of four different phases (representing, one turbid and one intermediate state of co-existing clear and turbid water, and two clear states, an intial and a final clear state) in the eutrophication and recovery of Lake Veluwe are summarized below. Regime shifts typify transitions between those phases:

- Phase 1: initial clear state 1957-1970 Lake Veluwe was clear with extensive meadows of charo- 

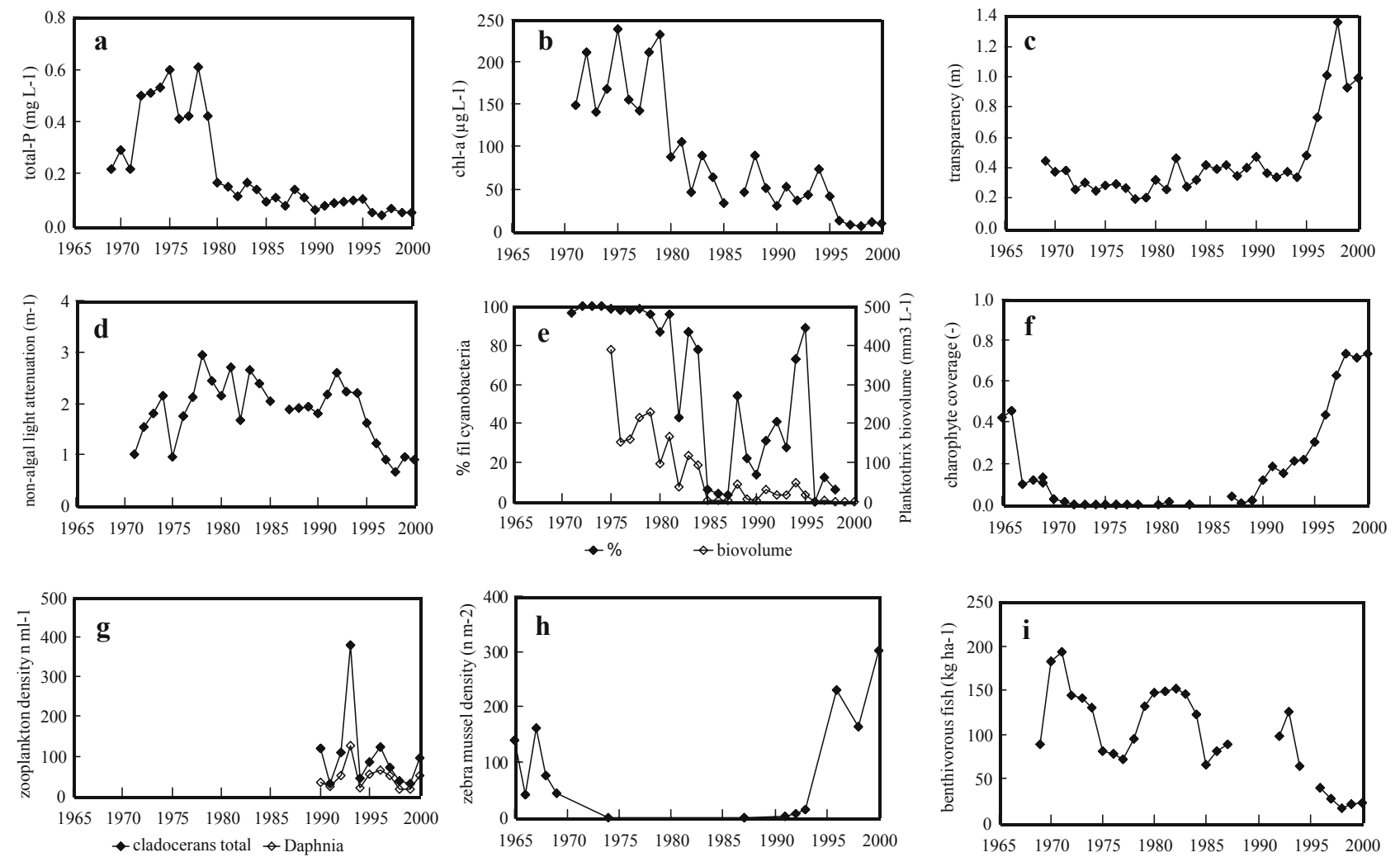

Figure 2. Patterns in A total $P$; $\mathbf{B}$ chlorophyll a; $\mathbf{C}$ transparency; D vertical light attenuation coefficient not related to phytoplankton ( = background turbidity); E biovolume of Planktothrix agardhii, as well as the percentage of the phyto plankton consisting of Planktothrix filaments; F internal charophyte coverage; G numbers of Daphnia spp; H density of zebra mussels; and I biomass of benthivorous fish in Lake Veluwe between 1965 and 2000. Early data on charophyte coverage and zebra mussel densities were reconstructed from bird numbers (see text for an explanation).

Table 2. Criteria that Separate Three Stages in the Recovery of Lake Veluwe from Eutrophication: The Initial Turbid State, an Intermediate State on the Route to Recovery and the Final Clear Water State

\begin{tabular}{llll}
\hline & Turbid & Intermediate & Clear \\
\hline TP $\left(\mathrm{mg} \mathrm{l}^{-1}\right)$ & $>0.1$ & 0.060 .1 & 0.040 .06 \\
TN $\left(\mathrm{mg} \mathrm{l}^{-1}\right)$ & $>2.2$ & 1.352 .2 & $<1.35$ \\
Chl $a\left(\mathrm{mg} \mathrm{m}^{-3}\right)$ & $>50$ & 1050 & $<10$ \\
Transparency $\left(\mathrm{m}^{-1}\right)$ & $<0.4$ & 0.41 .0 & $>1.0$ \\
Phytoplankton & Planktothrix bloom & Diverse community & Planktothrix absent \\
Daphnia grazing $\left(\mathrm{d}^{-1}\right)$ & $<0.4$ & $>0.4$ in clear water phase & $>0.4$ all summer \\
Dreissena & Absent & Increasingly present & $>300{\text { ind } \mathrm{m}^{-2}}$ \\
Chara & Absent & Colonization & $>30 \%$ internal coverage \\
Fish & Benthivorous & Perch and roach & Piscivorous = Planktivorous \\
Birds & Low numbers & Increasing & Carrying capacity
\end{tabular}

phytes; the lake bottom was visible throughout the lake, even in summer. Planktothrix was absent, but small 'blooms' of Microcystis occurred in late summer (observations in Leentvaar 1961). In the final years of this period charophyte coverage was already much reduced, as was transparency (Figure 2C, F).

- Phase 2: turbid state 1971-1985 Chara was absent. Year-round blooms of Planktothrix were observed (Berger 1987). A strong reduction in P-loading, starting in 1979, resulted in a prompt reduction of TP and Chl-a levels (decreasing to 
values around $50 \mu \mathrm{g}^{1}$ from peak values $>200 \mu \mathrm{g} 1^{1}$ ). However, transparency did not improve; pre 1979 Chl-a made up a major part of light attenuation, post 1979 non-algal light attenuation predominated.

- Phase 3: co-existence clear and turbid water, beginning of the recovery 1986-1995 Planktothrix no longer dominated the phytoplankton composition, following a string of severe winters (Jagtman and others 1992; Reeders and others 1998). Some years later the first recolonization by Chara of the shallowest parts of the lake occurred. During this period, clear (above charophytes) and turbid water (deeper parts of the lake) existed side by side. The biomass of benthivorous fish initially was still high in open water, but from 1994 onwards, there was a stepwise reduction in the biomass that coincided with a rapid expansion of Chara to the deeper parts of the lake and a return of zebra mussels to Lake Veluwe (see Figure 2).

- Phase 4: final clear state, full recovery 1996 - present Lake wide clear water (transparency $>1 \mathrm{~m}$ over long periods), stabilized by high Chara coverage and high density of Dreissena. Bream as the dominant fish species was replaced by planktivorous species, like perch (Perca fluviatilis) and roach (Rutilus rutilus). A temporary loss of transparency in 2002 was related to large scale dredging in the lake and record levels of precipitation; clear water state showed resilience because transparency returned to high values from 2003 onwards after dredging had finished.

Multivariate regression analysis (presented in Portielje and Rijsdijk 2003) showed that charophyte coverage was the principal factor influencing the (reduction in) algal turbidity. Non-algal light attenuation was mainly correlated with benthivorous fish biomass, whilst in this case the charophyte coverage was not a significant factor $(P>0.05)$. This suggests that the main events in the recovery of Lake Veluwe were the initial recolonization and steady expansion of charophytes and reduction in benthivorous fish, which may have allowed the expansion of Chara to the deeper parts of the lake. Expansion of Chara is also dependent on the build up of a sizeable propagule bank, and this is one of the factors that contributed to a pattern of gradual colonization of the lake (Van den Berg and others 2001). Zebra mussels only increased to a high density exceeding 200 animals $\mathrm{m}^{2}$ in 1996 once charophytes had already reached a moderate coverage of more than 0.3 and bream had been reduced from 120 to 40 $\mathrm{kg}$ ha ${ }^{1}$ by intensive fishery (Lammens and others
2004). Thus, mussels seem to have strengthened rather than initiated the clear water state. However, data for zebra mussels were available for 8 years only. Regression analysis on those eight years indicated once more that charophyte coverage is a better predictor for light attenuation $\left(R^{2}=0.64, n=8\right)$ than zebra mussel density $\left(R^{2}=0.16, n=8\right)$. This is in contrast to the situation in several North American lakes where invasion of zebra mussels cleared the water sufficiently to stimulate the development of macrophytes (Griffiths 1992). Zebra mussels are negatively affected by bream, both through physical disturbance and resuspension of inorganic sediment particles. We cannot be sure about the route to full recovery if bream had not been removed, but it seems likely that expansion of Chara to the deepest parts at the initial high bream density of $120 \mathrm{~kg}$ ha ${ }^{1}$ would have been hindered and the zebra mussel population would not have been established (Lammens and others 2004).

Zooplankton abundance in Lake Veluwe commonly followed a clear seasonal pattern, with the highest densities in spring and reduced abundance in summer. From 1994 onwards zooplankton may have been able to control phytoplankton in spring, but from June-July onwards planktivorous fish often eliminated the larger Daphnia and top-down control of phytoplankton by zooplankton grazing disappeared (Meijer and Hosper 1997). The role of zooplankton in maintaining clear water in lakes that are rich in submerged macrophytes is subject to discussion. Whereas Jeppesen and others (1999) put forward that zooplankton grazing plays a major role, Blindow and others (2002) present evidence for the opposite. For Lake Veluwe, data on zooplankton are only available from 1990 onwards and do not allow assessment of the potential role of Daphnia in reducing Chl- $a$ in the early stages of lake recovery. What we can say is that unlike the density of the other main phytoplankton grazer in the lake (Dreissena), the numbers of zooplankton did not show a positive trend in a period of major change in Lake Veluwe, the lake wide return of clear water (see Figure 2C, G, H). Because Chl- $a$ in this period (1990-2000) decreased from around 50 to less than $10 \mu \mathrm{g} \mathrm{l}^{1}$ the ratio of zooplankton : phytoplankton increased nevertheless, as is often seen during oligotrophication (Jeppesen and others 2005), so that the relative grazing pressure by zooplankton must have increased.

When data on transparency from over 30 years of monitoring are plotted as a function of $\mathrm{TP}$, again 


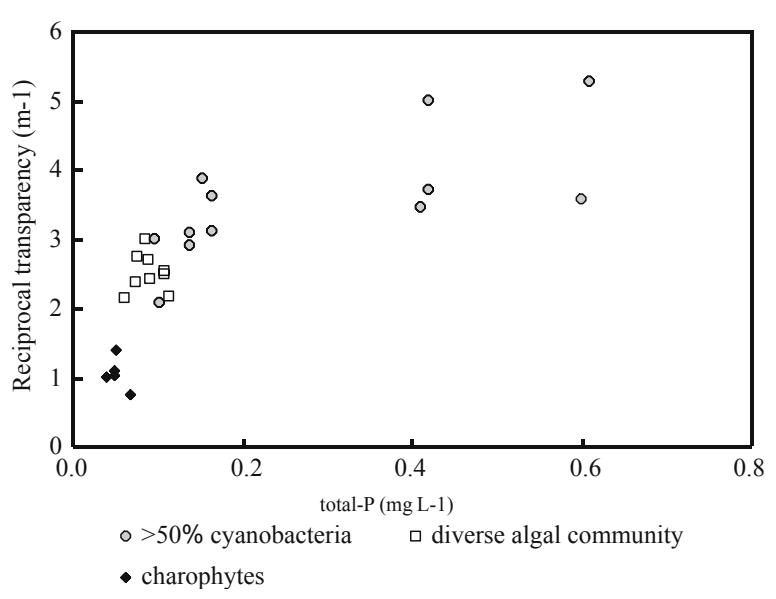

Figure 3. Summer mean turbidity, expressed as re ciprocal Secchi depth, versus summer mean total $\mathrm{P}$ in years with dominance of filamentous cyanobacteria, years with a diverse phytoplankton community, and years in which charophytes were abundantly present.

three alternative states can be distinguished. Figure 3 plots transparency and discriminates between years in which (1) Planktothrix still dominated, (2) filamentous cyanobacteria had been replaced by a mixed phytoplankton community, and (3) years in which Chara had regained a large coverage in the lake. Figure 4 shows that in the three states the frequency distributions of Chl- $a$ : TP and the nonalgal light attenuation were significantly different between the turbid and clear water state, whilst the intermediate state did not significantly differ from the turbid state (when more data points are included in the analysis by pooling data from Lake Veluwe with the bordering Lake Wolderwijd, which has a very similar eutrophication history, all 3 stages come out significantly different).

In summary, the recovery was initiated by the restoration measures that were taken to reduce TP. Phosphorus loading to Lake Veluwe was mainly reduced in one big step in 1979. The system responded promptly to the reduced external loading in phosphorus: in-lake TP and Chl-a levels dropped to values roughly $1 / 4$ of their previous peak values (Figure 2A, B). Hence phytoplankton (including Planktothrix) seemed to be under direct-bottom up control-of phosphorus. The response of lakes to a reduction in TP is often delayed because of loading of the top sediment layer during years of eutrophication (Sondergaard and others 2001). The short residence time of the water in Lake Veluwe (flushed in winter with water low in $\mathrm{P}$, rich in $\mathrm{Ca}$, that is, the residence time was decreased at the time when restoration measures were taken, but was longer during the period of eutrophication-see Jeppesen and others 2005 for discussion), combined with a high $\mathrm{pH}$ buffering capacity and a typical hydrology (high infiltration rates towards the adjacent polder) reduced the significance of internal P-loading (see Van der Molen and others 1998 for an extensive discussion). The response in transparency to the reduction in TP was still much delayed, however (Figure 2C), mainly because a pool of easily resuspended matter had built up, and this maintained the non-algal component of light attenuation at a high level. The turbid state was characterized by an initial period (1970-1976) in which Chl- $a$ determined most of the light attenuation. Gradually, however, the non-algal component started to build up too, so that in the late 1970s both components contributed equally to light attenuation (Figure 2B, D). This was followed by a period (beyond 1979) in which non-algal light attenuation remained at high values exceeding $2 \mathrm{~m}^{1}$, whilst attenuation by Chl- $a$ was reduced to less than $0.5 \mathrm{~m}^{1}$. The first events related to a return to clear water were the loss of Planktothrix as the dominant phytoplankton species, (Figure 2E) and a return of charophytes to the shallow parts of Lake Veluwe (Figure 2F). The reduction of bream from 1994 onwards (Figure 2I) presumably promoted the expansion of charophytes to deeper water-also depending on the ongoing build up of a propagule bank (Van Den Berg and others 2001) - and the return of zebra mussels to Lake Veluwe (Figure $2 \mathrm{H}$ ), and together these changes in the biological communities led to the establishment of a stable, resilient clear water state.

\section{Hysteresis}

Several different but interrelated forms of hysteresis in relation to TP were found during the recovery. Turbidity in relation to TP showed a marked hysteresis in Lake Veluwe (Figure 5A). Statistical analysis of the data, using the sign test, shows that the data points originating from the period of increasing eutrophication (pre 1979) are significantly $(P=0.006)$ below the dotted line that represents the 'average' relation of turbidity versus TP. This line was constructed by fitting the data to a Monod type equation using least squares optimization (Sokal and Rohlf 1995). Data from the period of decreasing TP concentrations (1979 and further) are significantly $(P=0.02)$ above the dotted line. Closely related is the hysteresis that occurred in the non-algal component of light attenuation (Figure 5B), which increased heavily in the period 1974-1978, several years after the 

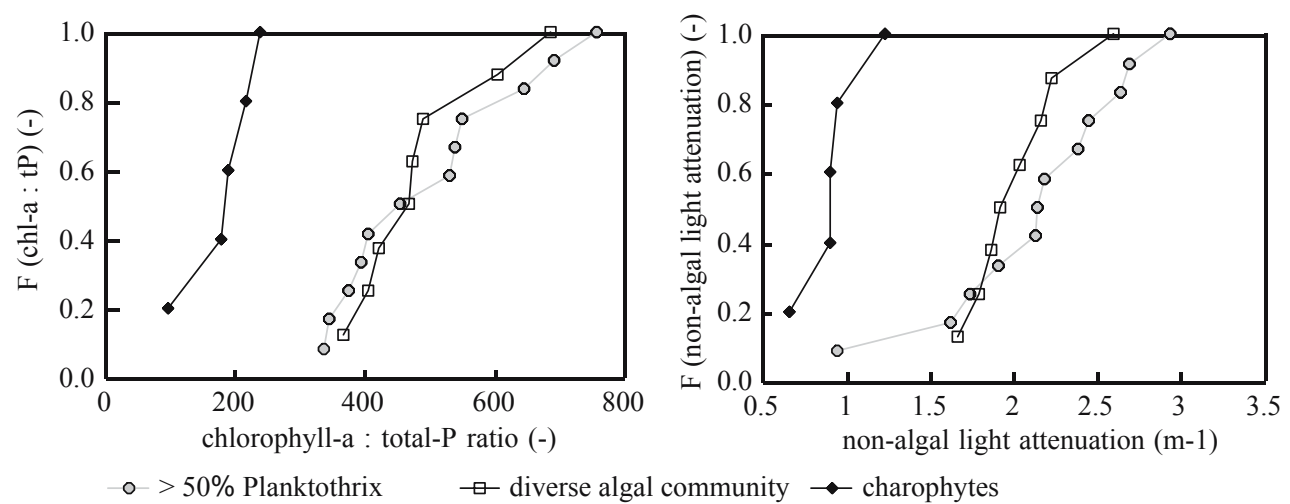

Figure 4. Cumulative frequency distributions of $\mathbf{A}$ the $\mathrm{Chl} a$ : TP ratio anzd $\mathbf{B}$ non algal component of light attenuation in years dominated by filamentous cyanobacteria, years with a more diverse phytoplankton community, and years in which charophytes were abundantly present. The Wilcoxon ranking test showed that frequency distributions of 'Chara years' differ significantly from years in which phytoplankton dominated.

disappearance of the charophytes from Lake Veluwe, and when algal biomass and TP concentrations were already high. This background turbidity decreased only slowly after the reduction of TP and for a long time remained at the same high level.

The disappearance of charophytes in the 1960s and their re-appearance in the early 1990s also shows a marked hysteresis with respect to TP (Figure 5c). Although no precise data on both charophyte coverage and TP in the early and mid 1960s exist (for an explanation on how data were derived see the Methods section), concentrations of TP estimated from COD:TP ratios were considerably higher than TP concentrations when charophytes returned to Lake Veluwe some 2030 years later. For the period 1960-1968 the areal fraction of the lake that was covered with charophytes ranged from 0.6 in the early 1960s to 0.1 in 1967 and 1968. In 1969, the first year with actual measurements, considerable charophyte coverage was still present in Lake Veluwe, whilst the summer mean TP concentration already exceeded $0.20 \mathrm{mg} \mathrm{l}^{\mathrm{l}}$. After 1969 the charophytes disappeared altogether and the lake ecosystem completed its shift to a turbid state with historically low levels of transparency (further $50 \%$ reduction to $<0.2 \mathrm{~m}$ ). The restoration process followed a different route. The summer mean TP concentration had declined below $0.10 \mathrm{mg} \mathrm{l}^{1}$ before the first charophytes returned around 1990. The time course of charophytes versus TP as shown in Figure 5C thus shows that their recovery occurred at lower TP than their fall in the 1960s, indicating hysteresis.

The disappearance and recovery of the zebra mussels in Lake Veluwe in relation to TP show a comparable pattern of hysteresis (Figure 5D). The historical mussel densities in the 1960s and early 1970s reconstructed from bird numbers of goldeneye (Bucephala clangula), pochards (Aythya ferina) and tufted duck (Aythya fuligula) indicate a complete disappearance of the mussels during the period 1967-1970, again at higher TP than during their return in the second half of the 1990s.

Unfortunately hysteresis in the phytoplankton (expressed either as Chl- $a$ or abundance of Planktothrix) cannot be demonstrated in the same way because Chl- $a$ levels already exceeded $200 \mu \mathrm{g} \mathrm{l}{ }^{1}$ in the early 1970s and Planktothrix was already dominating the phytoplankton when monitoring began (we have data on the downward trend in Chl-a after nutrient reduction in 1979, but lack data on the upward trend with eutrophication in the 1960s). What can be said is that TP in those first years in which Planktothrix dominated the summer phytoplankton community (described by Berger 1975, 1987) exceeded $0.2 \mathrm{mg} \mathrm{l}^{1}$, whilst TP was only half that value in 1985, at the time when Planktothrix disappeared as the dominant species in the phytoplankton.

All of our analyses focus on hysteresis related to TP. Recently, Gonzalez and others (2005) concluded that the importance of nitrogen in lake hysteresis may have been underestimated. No complete dataset is available for $\mathrm{N}$ in Lake Veluwe. The earliest measurement is from 1977 when TN exceeded $6 \mathrm{mg} \mathrm{l}^{1}$. In the period when macrophytes returned and expanded, N-levels were much lower than in the 1970s, but in most years they still exceeded $2 \mathrm{mg} \mathrm{l}^{1}$. A survey of Danish shallow lakes showed that high macrophyte coverage occurred only when summer mean TN was below $2 \mathrm{mg} \mathrm{N} \mathrm{l}^{-1}$, irrespective of the concentration of TP, which varied between 0.03 and $1.2 \mathrm{mg} \mathrm{l}^{1}$ 

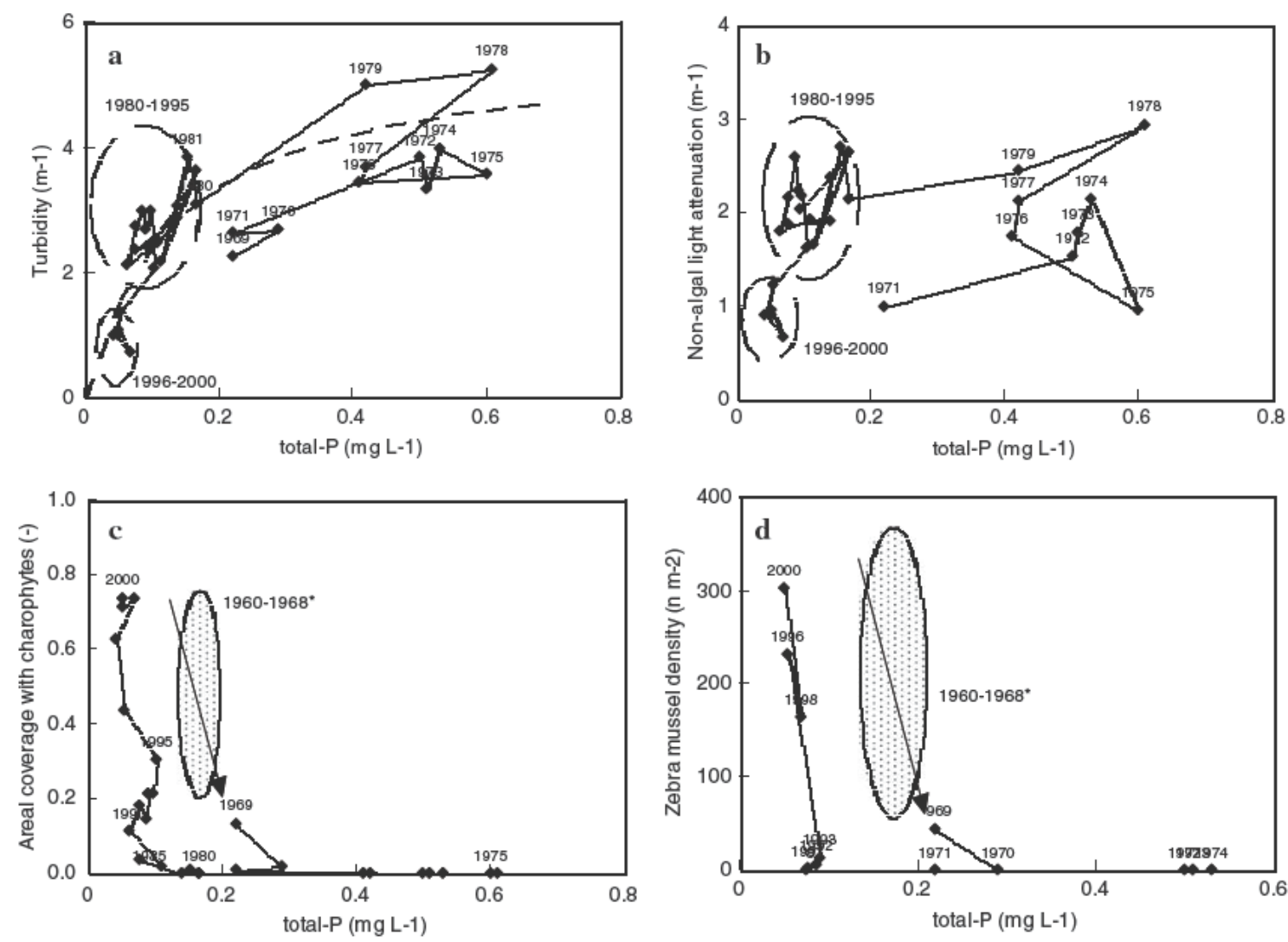

Figure 5. Time course indicating hysteresis of $\mathbf{A}$ reciprocal transparency; $\mathbf{B}$ non algal light attenuation; C charophyte coverage; D zebra mussel density versus summer mean TP in Lake Veluwe. Dotted lines in (A) represent a Monod type equation for the fitted turbidity to TP relationship: reciprocal transparency $=5.64 *[\operatorname{total} P] /([$ total $P]+0.133)\left(\mathrm{m}^{-1}\right)$.

(Gonzalez and others 2005). High N concentrations may have been prohibitive for the expansion of Chara in Lake Veluwe. Summer average levels of TN were below the threshold (around $1.2 \mathrm{mg} \mathrm{l}^{1}$ ) in 1996 and 1997, years when Chara showed it most rapid expansion (coverage from $<0.3$ to $>0.6$; Figure $2 \mathrm{~F}$ ). It is possible that relatively high $\mathrm{N}$ levels have contributed to hysteresis in the recovery of Lake Veluwe, as suggested by Gonzalez and others (2005), but we cannot confirm this.

\section{Discussion}

Clear water with abundant macrophytes is the reference situation for lakes in the Netherlands. The EU Water Framework Directive demands that lakes should (at least) approach this reference situation by 2015. Currently however, many of the lakes are still in the turbid state, despite decades of nutrient control measures. Additional efforts are required to overcome hysteresis and to achieve a shift to clear water and macrophyte dominance. The aim of this paper is to improve our understanding about the occurrence of alternative stable states and hysteresis in the recovery of shallow lakes from eutrophication. We do so by analyzing more than 30 years of data of a well-studied lake, Lake Veluwe. It should be noted, however, that field data alone cannot provide conclusive evidence for the occurrence of alternative stable states (Scheffer and others 2001; Scheffer and Carpenter 2003). However, hints from field data may for instance be found in: (1) abrupt changes in time series; (2) dual relationships to control factors; (3) regime shifts triggered by disturbance, and (4) hysteresis. Support for these factors can be found in the monitoring data of Lake Veluwe as discussed below.

After its formation, Lake Veluwe remained clear with an abundant presence of charophytes (Leentvaar 1961). Research has shown the importance of macrophytes in maintaining a stable clear water state (for example, Blindow and others 2002) or-following the definition of Gunderson (2000) - in strengthening the resilience of the system under pressure of eutrophication. The turbid state also showed resilience: it resisted a shift back to the clear state, despite successful efforts to re- 
duce TP drastically. Hysteresis in the recovery can be seen in both abiotic factors and biological communities (Figure 5). Degraded systems are often characterized by species that respond differently to interactions that maintained the structure and composition of the original state (Suding and others 2004). This may have been the case in Lake Veluwe, where dense blooms of filamentous cyanobacteria were a distinctive feature of the early stages of the turbid state. Filamentous cyanobacteria cannot be grazed easily by filter feeders like Daphnia (unlike Dreissena) (Dionisio Pires and others 2005), and this may have prevented a spring clear water phase, with obvious negative consequences for establishment of macrophytes. Planktothrix, through its physiological-for example, a low energy maintenance coefficient-and morphological characteristics, is well adapted to growth in turbid water (Mur and others 1978; Reynolds 1997). Early on in the turbid state (pre 1979), Planktothrix thus maintained the turbid environment that fostered its own persistence. The degree of shade (quantified as the product of depth and light attenuation) created by Planktothrix in Lake Veluwe was significantly higher than that created by a mixed phytoplankton community, typical of the intermediate phase of lake recovery (Scheffer and others 1997). It is an example of a dual relationship to control factors (Scheffer and Carpenter 2001).

Gradually the reduction in TP in 1979 was followed by changes in the phytoplankton community, and the long-term dominance of Planktothrix was broken. The number of Planktothrix filaments and its biovolume (Figure 2) were reduced in the early period of recovery of Lake Veluwe. However, Planktothrix remained the dominant species until the mid 1980s, when it was replaced by a more mixed phytoplankton community. The high level of non-algal light attenuation presumably made it difficult for other species to compete in the lake at that time, and background turbidity was reduced to less than $2 \mathrm{~m}^{1}$ before Planktothrix lost its dominant position. Factors other than improvement of the underwater light climate may have contributed to a shift in phytoplankton too. The mid 1980s were characterized by long periods of ice cover in a string of cold winters. A severe winter results in a low inoculum of filamentous cyanobacteria, which may reduce the size of the summer blooms (Jagtman and others 1992; Reeders and others 1998). The size of the inoculum is especially important for relatively slow growing phytoplankton like larger cyanobacterial species (Reynolds 1997). It is typical that often the proximate-but not ultimate-cause of a regime shift is of a stochastic nature, like variations in climate. Lowe and others (2001) contest the view of Bachmann and others (1999) that storms initiated and maintained turbid water in Lake Apopka, Florida. In contrast, they put forward that wind disturbance may have accelerated the collapse of the submerged vegetation, but that in the period before eutrophication wind disturbance was insufficient to shift the lake into a turbid state.

Arguably one of the pivotal steps in the recovery of Lake Veluwe was the re-colonization of the shallowest areas by charophytes, which locally led to clear water (Scheffer and others 1994; Coops and Doef 1996). The sharp transition zones between turbid and clear water provide a spatial analogue to the jumps that can be seen in the time series of, for instance, transparency or Chara coverage. This spatial heterogeneity that was maintained over a number of years can be taken as further support for the existence of alternative stable states. Even early in the recovery, the local clear water state above the charophytes was quite stable and was restored quickly after a storm (Scheffer and others 1994).

The final step in the restoration occurred when the area with clear water expanded to the whole lake, that is, transparency was high even outside the plant beds. Reduction in bream density must have been one of the important steps promoting the transition to the final stage in lake recovery (Lammens and others 2004). An acceleration in lake recovery is evident from the sigmoidal increases in transparency, charophyte coverage, and zebra mussel density (see Figure 2), and is in accordance with theory (Scheffer and others 2001; Scheffer and Carpenter 2003). The very low phytoplankton biomass in this period cannot be explained by the reduced TP concentrations only, as also the ratio Chl- $a$ : TP was reduced significantly (see Figure 4). This may have been caused by feedback mechanisms of submerged macrophytes that control phytoplankton (Van Donk and Van De Bund 2002), as well as by the high filtration rate of zebra mussels that returned to Lake Veluwe in large numbers. Dreissena can only develop under conditions of limited silt sedimentation as they need a firm substrate (Dionisio Pires and Van Donk 2002). Through filtration and the excretion of (pseudo) fecal pellets with a relatively high settling velocity, mussels thus improve their own habitat, and help to maintain the stability of the clear water state. Interestingly, invasion by Dreissena has been implicated in a return of cyanobacterial blooms to some of the North American Great Lakes. The complexity of direct (grazing) and indirect (for 


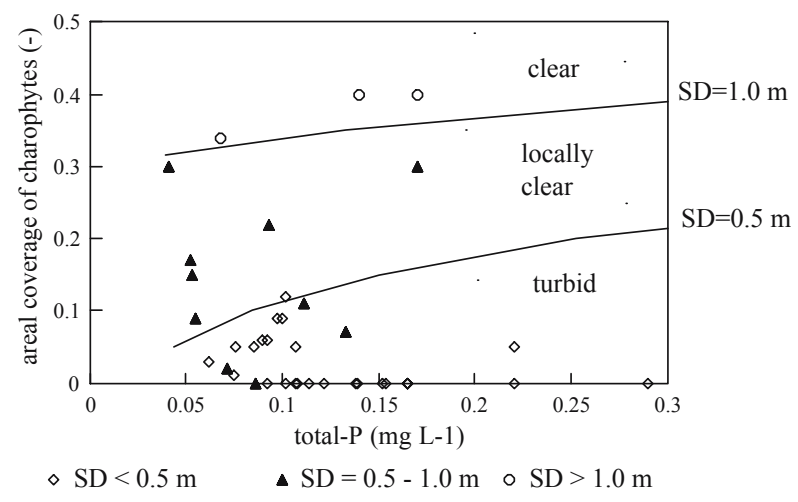

Figure 6. Dependence of critical transparencies of 0.5 and $1 \mathrm{~m}$ on TP and (internal) macrophyte coverage. A transparency of greater than $1 \mathrm{~m}$ can only be achieved when internal macrophyte coverage exceeds 30\% (see graph, upper line). In the absence of charophytes the lake is turbid unless TP is very low. Isohypse lines were calculated as the TP concentrations for which the median simulated value of summer mean transparency (SD) equaled 0.5 and $1.0 \mathrm{~m}$ respectively, using the stochastic model described by Portielje and Rijsdijk (2003). Indi vidual data points are based on field measurements.

example, nutrient recycling) effects of mussels on phytoplankton in lakes of different nutrient status may explain why these zebra mussels may have such contrasting effects in different ecosystems (see Sarnelle and others 2005).

We have argued in this paper that (re-)colonization of the lake by macrophytes and mussels, as well as the reduction in benthivorous fish played key roles in the recovery of Lake Veluwe. For future management of the lake it is perhaps as critical to maintain a proper equilibrium between the biological communities as it is to control nutrients. Figure 6 shows how transparency depends on TP and macrophyte coverage. The figure distinguishes between transparencies of 0.5 and $1.0 \mathrm{~m}$, which were typical for the intermediate, respectively final phase of lake recovery. A transparency of greater than $1 \mathrm{~m}$ can only be achieved when internal macrophyte coverage exceeds $30 \%$, unless TP is very low. If charophytes are abundantly present, transparency appears not to be very sensitive to (limited) increases in TP; there is only a small risk of a collapse into the turbid state. Phosphorus loading to Lake Veluwe is indeed likely to increase in the future (argumentation given in Portielje and Rijsdijk (2003), that is, increased precipitation, resulting in discharge from the small streams that flow into Lake Veluwe, and that have their catchments in agricultural areas) and-as the past has shown-there are limits to what the lake ecosystem can handle (resilience). Even a resilient clear water state will be lost when P-loading exceeds certain thresholds. Original attempts to abate eutrophication in the Netherlands were focused on control of phosphorus only. It was soon realized, however, that in many cases this was insufficient to destabilize the turbid state. Biomanipulation became a popular tool for lake management in the Netherlands (Meijer and others 1999). In Lake Veluwe, care should be taken to preserve Chara coverage, but handling of Dreissena and fish stocks also requires attention. When the biota are managed properly TP concentrations of $0.1-0.15 \mathrm{mg} \mathrm{l}^{1}$ should not be fatal to the clear water state (Portielje and Rijsdijk 2003).

The analysis of decades of monitoring data of Lake Veluwe, as done in this paper, provides an example of the occurrence of alternative stable states and hysteresis during lake recovery from eutrophication. Although we discuss the likely drivers of the regime shifts, formal demonstration of cause and effect is not possible on the basis of field data only (Havens and Aumen 2000). Whether the existence of alternative stable states in shallow lakes can truly be proven may, however, not be directly relevant to lake management. Ignoring the possibility of catastrophic regime shifts has proven costly and may send restoration efforts in the wrong direction (Suding and others 2004). Gunderson (2000) calls for 'adaptive management': we should acknowledge that ecosystem behavior is unpredictable and should not strive to control this. Efforts to reduce the risk of unwanted regime shifts should primarily focus on maintaining ecosystem resilience through balanced management of nutrients and lake communities alike.

\section{ACKNOWLEDGMENTS}

The work presented here was supported financially through the years by The Dutch Ministry of Transport, Public Works and Water Management. We gratefully acknowledge Prof. Erik Jeppesen, Prof. Karl Havens, an anonymous reviewer and Dr. Miguel Dioniso Pires for their constructive comments on an earlier version of the manuscript.

\section{REFERENCES}

Bachmann RW, Hoyer Canfield MV DE. 1999. The restoration of Lake Apopka in relation to alternative stable states. Hydrobi ologia 394:219 32.

Bayley SE, Prather CM. 2003. Do wetland lakes exhibit alter native stable states? Submersed aquatic vegetation and chlo rophyll in western boreal shallow lakes. Limnol Oceanograph 48:2335 45 . 
Berger C. 1975. Occurrence of Oscillatoria agardhii Gom. in some shallow eutrophic lakes. Verhandlungen Internationale Vereinigung Limnologie 19:2689 97.

Berger C, 1987. Habitat en ecologie van Oscillatoria agardhii Gomont. PhD Thesis University of Groningen.233 pp. ISBN 9036910250.

Blindow I, Hargeby A, Andersson G. 2002. Seasonal changes of mechanisms maintaining clear water in a shallow lake with abundant Chara vegetation. Aquat Bot 72:315 34 .

Coops H, Doef RW. 1996. Submerged vegetation development in two shallow lakes. Hydrobiologia 340:115 20.

Dent CL, Cumming GS, Carpenter SR. 2002. Multiple states in river and lake ecosystems. Philosophical Trans R Soc Lond Series B Biol Sci 357:635 45.

Dionisio Pires LM, Van Donk E. 2002. Comparing grazing by Dreissena polymorpha on phytoplankton in the presence of toxic and non toxic cyanobacteria. Freshwater Biol 47:1855 65.

Dionisio Pires LM, Ibelings BW, Brehm M, Van Donk E. 2005. Comparing grazing on lake seston by Dreissena and Daphnia: lessons for biomanipulation. Microb Ecol 50:242 252.

Dokulil MT, Teubner K. 2003. Eutrophication and restoration of shallow lakes the concept of stable equilibria revisited. Hydrobiologia 506:29 35 .

Gonzalez SMA, Jeppesen E, Goma J, Sondergaard M, Jensen JP, Lauridsen T, Landkildehus F. 2005. Does high nitrogen load ing prevent clear water conditions in shallow lakes at mod erately high phosphorous concentrations?. Freshwater Biol 50:27 41.

Griffiths RW. 1992. Effects of zebra mussels (Dreissena poly morpha) on the benthic fauna of Lake St. Clair. In: Nalepa DW, ed. Zebra mussels biology, impacts and control. Lewis Publishers. pp 41537.

Gunderson LH. 2000. Ecological resilience in theory and application. Ann Rev Ecol Syst 31:425 39.

Havens KE, Aumen NG. 2000. Hypothesis driven experimental research is necessary for natural resource management. Environ Manag 25:1 7.

Holling CS. 1973. Resilience and stability of ecological systems. Ann Rev Ecol Syst 4:1 23.

Hosper SH. 1997. Clearing lakes. An ecosystem approach to the restoration and management of shallow lakes in the Nether lands. RIZA (Lelystad). 168 pp. ISBN 9054856823.

Jackson LJ. 2003. Macrophyte dominated and turbid states of shallow lakes: evidence from Alberta Lakes. Ecosystems 6:213 23.

Jagtman E, Van der Molen DT, Vermij S. 1992. The influence of flushing on nutrient dynamics, composition and densities of algae and transparency in Veluwemeer, The Netherlands. Hydrobiologia 233:187 96.

Jeppesen EJP, Jensen M, Sondergaard M, Lauridsen T. 1999. Trophic dynamics in turbid and clear water lakes with special emphasis on the role of zooplankton for water clarity. Hyd robiologia 409:217 31 .

Jeppesen E, Sondergaard M, Jensen JP, Havens KE, Anneville O, Carvalho L, Coveny MF, Deneke R, Dokulil MT, Foy B, Ger deaux D, Hampton SE, Hilt S, Kangur K, Kohler L, Lammens EHRR, Lauridsen TL, Manca M, Miracle MR, Moss B, Noges P, Persson G, Phillips G, Portielje R, Romo S, Schelske CL, Straile D, Tatrai, Willen E, Winder M. 2005. Lake responses to nutrient loading an analysis of contemporary long term data from 35 case studies. Freshwater Biol 50:1747 1771.
Korner S. 2001. Development of submerged macrophytes in shallow Lake Muggelsee (Berlin, Germany) before and after its switch to the phytoplankton dominated state. Archiv Fur Hydrobiologie 152:395 409.

Lammens EHRR, Van Nes EH, Mooij WM. 2002. Differences in the exploitation of bream in three shallow lake systems and their relation to water quality. Freshwater Biol 47: 243542.

Lammens EHRR, Van Nes EH, Meijer ML, Van den Berg MS. 2004. Effects of commercial fishery on the bream population and the expansion of Chara aspera in Lake Veluwe. Ecol Mo dell 177:233 44.

Leentvaar P. 1961. Hydrobiologische waarnemingen in het Veluwemeer. De Levende Natuur 64:273 9.

Lowe EF, Battoe LE, Coveny LF, Schelske CL, Havens KE, Marzolf ER, Reddy KR. 2001. The restoration of Lake Apopka in relation to alternative stable states: an alternative view to that of Bachmann and others (1999). Hydrobiologia 448:11 8 .

Meijer ML, Hosper SH. 1997. Effects of biomanipulation in the large and shallow lake Wolderwijd. Hydrobiologia 342/ 343:335 49 .

Meijer ML, De Boois I, Scheffer M, Portielje R., Hosper H. 1999. Biomanipulation in shallow lakes in the Netherlands: an evaluation of 18 case studies. Hydrobiologia 409:13 30.

Moss B, Stansfield J, Irvine K, Perrow M, Phillips G. 1996. Progressive restoration of a shallow lake: A 12 year experi ment in isolation, sediment removal and biomanipulation. $\mathrm{J}$ Appl Ecol 33:71 86.

Mur LR, Gons HJ, Van Liere L. 1978. Competition of the green alga Scenedesmus and the blue green alga Oscillatoria. Miiteil ungen Internatnationale Vereins Limnologie 21:473 9.

Murphy J, Riley JP. 1962. A modified single solution method for the determination of phosphate in natural waters. Analytica Chimica Acta 27:31 6.

Noordhuis R, Van der Molen DT, Van der Berg MS. 2002. Re sponse of herbivorous water birds to the return of Chara in Lake Veluwemeer, the Netherlands. Aquat Bot 72:349 67.

Portielje R, Rijsdijk RE. 2003. Stochastic modeling of nutrient loading and lake ecosystem response in relation to submerged macrophytes and benthivorous fish. Freshwater Biol 48:741 55.

Portielje R, Van der Molen DT. 1999. Relationships between eutrophication variables: from nutrient loading to transpar ency. Hydrobiologia 409:375 87.

Reeders HHP, Boers PCM, Van der Molen DT, Helmerhorst TH. 1998. Cyanobacterial dominance in the lakes Veluwemeer and Wolderwijd, The Netherlands. Water Sci Technol 37:85 92.

Reynolds CS. 1997. Vegetation processes in the pelagic: a model for ecosystem theory. Ecology Institute (Oldedorf). $371 \mathrm{p}$.

Sarnelle O, Wilson AE, Hamilton SK, Knoll LB, Raikow DF. 2005. Complex interactions between the zebra mussel, Dreis sena polymorpha, and the harmful phytoplankter, Microcystis aeruginosa.. Limnol Ocenaograph 50:896 904.

Scheffer M. 1998. Ecology of shallow lakes. London: Chapman 8 Hall, p 357.

Scheffer M, Carpenter SR. 2003. Catastrophic regime shifts in ecosystems: linking theory to observation. Trends Ecol Evol 18:648 56.

Van den Scheffer Berg M. M, Breukelaar A, Coops H., Doef R., Meijer ML. 1994. Vegetated areas with clear water in turbid shallow lakes. Aquat Bot 49:193 6. 
Scheffer M, Rinaldi S, Gragnali A, Mur LR, Van Nes EH. 1997. On the dominance of filamentous cyanobacteria in shallow, turbid lakes. Ecology 78:272 82 .

Scheffer M, Carpenter SR, Foley JA, Folke C, Walker B. 2001. Catastrophic shifts in ecosystems. Nature 413:591 596.

Scheffer M, Portielje R, Zambrano L. 2003. Fish facilitate wave resuspension of sediment. Limnol Oceanograph 48:1920 6 .

Schriver P, Bogestand J, Jeppesen E, Sondergaard M. 1995. Impact of submerged macrophytes on fish zooplankton phytoplankton interactions large scale enclosure experi ments in a shallow eutrophic lake. Freshwater Biol 33:255 70.

Sokal RR, Rohlf FJ. 1995. Biometry: the principles and practice of statistics in biological research. 3rd edn. New York: W. H. Freeman and Co. pp 887 ISBN: 0716724111.

Sondergaard M, Jensen JP, Jeppesen E. 2003. Role of sediment and internal loading of phosphorus in shallow lakes. Hydro biologia 506:135 145 .

Suding KN, Gross KL, Houseman GR. 2004. Alternative states and positive feedbacks in restoration ecology. Trends Ecol Evol 19:46 53.

Van Den Berg M, Scheffer M, Coops H, Simons J. 1998. The role of Characean algae in the management of eutrophic shallow lakes. J Phycol 34:750 6.
Van Den Berg MS, Scheffer M, Van Nes EH, Coops H. 1999. Dynamics and stability of Chara sp and Potamogeton pectinatus in a shallow lake changing in eutrophication level. Hydrobi ologia 409:335 42 .

Van Den Berg M, Coops H., Simons J. 2001. Propagule bank buildup of Chara aspera and its significance for colonization of a shallow lake. Hydrobiologia 462:9 17.

Van Der Molen DT, Portielje R, Boers PCM, Lijklema L. 1998. Changes in sediment phosphorus as a result of eutrophication and oligotrophication in Lake Veluwe, The Netherlands. Wa ter Res 32:3281 88.

Van Der Molen DT, Portielje R. 1999. Multi lake studies in The Netherlands: trends in eutrophication. Hydrobiologia 409:359 65 .

Van Donk E, Van De Bund WJ. 2002. Impact of submerged macrophytes including charophytes on phyto and zoo plankton communities: allelopathy versus other mechanisms. Aquat Bot 72:261 74 .

Verdugt N. 1981. De gevolgen van de aflsuiting van de Zuiderzee en de inpoldering van Flevoland voor de waterkwaliteit in het IJsselmeergebied. Rapport 1981 305. Rijksdienst voor de IJs selmeerpolders. 